\title{
Donnan Membrane Process for the Selective Recovery and Removal of Target Metal Ions-A Mini Review
}

\author{
Dennis Asante-Sackey ${ }^{1}\left(\mathbb{D}\right.$, Sudesh Rathilal ${ }^{1}\left(\mathbb{D}\right.$, Emmanuel Kweinor Tetteh ${ }^{1, *} \mathbb{(}$, Elorm Obotey Ezugbe ${ }^{1}(\mathbb{D})$ and \\ Lingham V. Pillay ${ }^{2}$ \\ 1 Department of Chemical Engineering, Durban University of Technology, Durban 4001, South Africa; \\ ingsackey@gmail.com (D.A.-S.); rathilals@dut.ac.za (S.R.); elormezugbe.ee6@gmail.com (E.O.E.) \\ 2 Department of Process Engineering, Stellenbosch University, Matieland 7600, South Africa; pillayvl@sun.ac.za \\ * Correspondence: ektetteh34@gmail.com or emmanuelk@dut.ac.za
}

check for updates

Citation: Asante-Sackey, D.; Rathilal S.; Kweinor Tetteh, E.; Ezugbe, E.O.; Pillay, L.V. Donnan Membrane Process for the Selective Recovery and Removal of Target Metal Ions-A Mini Review. Membranes 2021, 11, 358. https://doi.org/10.3390/

membranes 11050358

Academic Editors: Steven

J. Duranceau and Javier

Miguel Ochando-Pulido

Received: 28 February 2021

Accepted: 8 May 2021

Published: 14 May 2021

Publisher's Note: MDPI stays neutral with regard to jurisdictional claims in published maps and institutional affiliations.

Copyright: (c) 2021 by the authors. Licensee MDPI, Basel, Switzerland. This article is an open access article distributed under the terms and conditions of the Creative Commons Attribution (CC BY) license (https:// creativecommons.org/licenses/by/ $4.0 /)$.

\begin{abstract}
Membrane-based water purification technologies contribute significantly to water settings, where it is imperative to use low-cost energy sources to make the process economically and technically competitive for large-scale applications. Donnan membrane processes (DMPs) are driven by a potential gradient across an ion exchange membrane and have an advantage over fouling in conventional pressure driven membrane technologies, which are gaining attention. DMP is a removal, recovery and recycling technology that is commonly used for separation, purification and the concentrating of metals in different water and waste streams. In this study, the principle and application of DMP for sustainable wastewater treatment and prospects of chemical remediation are reviewed and discussed. In addition, the separation of dissolved metal ions in wastewater settings without the use of pressure driven gradients or external energy supply membrane technologies is highlighted. Furthermore, DMP distinctive configurations and operational factors are explored and the prospects of integrating them into the wastewater treatment plants are recommended.
\end{abstract}

Keywords: Donnan membrane process; ion exchange membranes; metal recovery; Donnan Dialysis

\section{Introduction}

Metals, specifically heavy metals in effluent and sludge discharges from anthropogenic sources such as households, agriculture, manufacturing and process industries, are of major concern to environmental regulators [1-3]. Notable amongst the metals and those that are classified as the most hazardous metal species are $\mathrm{As}, \mathrm{Cr}, \mathrm{Ni}, \mathrm{Cd}, \mathrm{Pb}, \mathrm{Co}, \mathrm{Zn}$ and $\mathrm{Cu}$. Although the concentration of these metals very depending on the source, they are toxic and non-biodegradable, even at very low concentrations. Due to the high solubility of these metals, they are readily passed-on, absorbed and accumulated into the human body through the food chain, thereby causing cancers, neurological disorders, skin diseases, respiratory problems, congenital disorders, fertility decreases and chronic kidney damage [4-6].

Knowing the aforementioned impact on water, soil and air, public concerns have increased over the years resulting in stricter legislations, most especially in more developed countries [7]. However, various management and control schemes to address the adverse effects at their point sources and non-point sources have not achieved the extent of impact. While the presence of the metals in the discharges have been viewed as toxic and require complete removal, new age engineering considers them as a representation of a significant loss in raw materials. Sustainable treatment options in addressing the latter view, therefore, look at removal, recovery and reuse technologies (3Rs-Tech).

Ion exchange for the removal, recovery and reuse of metals is a widely known and effective treatment process. It is a selective, reversible and stoichiometric method that involves the displacement of ionic species by another ionic species in the exchanger [8]. The exchangers serve as sorbents and are either resins or membranes. Although the mention 
of ion exchange usually refers to resins, ion exchange membranes (IEMs) have gained prominence due to their dimensional stability over resins [9]. Wide spread use of IEMs include sea water desalination, water softening and purification, the chlor-alkali process, energy production and energy storage [10-12].

The Donnan membrane process (DMP), commonly referred to as Donnan Dialysis, is an emerging green treatment process that integrates IEMs. The first usage of DMP is attributed to Prakash and SenGupta [13]. The DMP involves the stoichiometric counter transport of ions across an IEM. As a concentration gradient driven process, DMP can be classified as a 3R-tech used in the recovery, separation and concentration of ions of interest from diluted solutions.

The DMP has often been interchanged with Diffusion Dialysis (DD) due to their indistinguishable principles of operation and application advantages. Whilst DD is utilized in the recovery of mineral acids or alkalis from waste acid and alkaline solutions, DMP is applied in the recovery of toxic or valuable heavy metal ions [14-16]. The simple and easy to operate DMP system exhibits functional advantages over the conventional ion exchange process, electrodialysis (ED), chemical precipitation and pressure driven membrane processes. The DMP is an energy efficient, low installation and operational cost, non-risen regeneration and a non-fouling process that possess rural application benefits [17-21]. Ion transport in a DMP occurs as long as the donor phase volume is greater than the receiver phase. Table 1 expounds on the advantages and disadvantages of some metal removal processes.

Table 1. Advantages and disadvantages of selected metal removal technologies.

\begin{tabular}{|c|c|c|c|}
\hline Process & Advantages & Disadvantage & References \\
\hline Conventional Ion exchange & $\begin{array}{l}\text { Low cost, high selectivity, little } \\
\text { or no use of organic solvents, } \\
\text { regeneration capability }\end{array}$ & $\begin{array}{l}\text { Resin regeneration requires chemical } \\
\text { addition, poor quality products, long } \\
\text { production cycle, finding suitable resin is a } \\
\text { challenge, process is highly pH sensitive. }\end{array}$ & {$[9,22]$} \\
\hline Pressure driven membranes & $\begin{array}{l}\text { Wide range application, simple } \\
\text { configuration, high removal } \\
\text { and rejection. }\end{array}$ & $\begin{array}{l}\text { Susceptible to fouling, complex reverse } \\
\text { cleaning process, additional pretreatment } \\
\text { process is costly, internal and external } \\
\text { concentration polarization depending on } \\
\text { membrane process, expensive and } \\
\text { non-recyclable drawing solutions for } \\
\text { forward osmosis process, enrichment of } \\
\text { contaminant in retentates causing secondary } \\
\text { pollution, non-rejection of monovalent ions } \\
\text { for nanofiltration, high energy demand for } \\
\text { pressure pumps used. }\end{array}$ & [23-28] \\
\hline
\end{tabular}
pressure pumps used.

High cost of absorbent, residue generation

Simple technology, wide range

Adsorption of metals selectivity, low cost local, materials readily available as natural absorbents, and disposal challenges, adsorbent regeneration complex and expensive, $\mathrm{pH}$ of solution affects sorption to binding sites, removal efficiency depends on type of sorbent, synthetic absorbent expensive to produce.

$\mathrm{pH}$ adjustment is critical as precipitates can resolubilize, high residue generation and disposal, high chemical demand, large tanks at high installation costs, energy inputs required, generation of $\mathrm{H}_{2} \mathrm{~S}$ for sulfide reagent, $\mathrm{CO}_{2}$ for carbonate reagent.
Simple, low cost of precipitant, Chemical precipitation non-selective, shorter removal time.
[33-36]
[29-32]

$$
[33-36]
$$


Table 1. Cont.

\begin{tabular}{|c|c|c|c|}
\hline Process & Advantages & Disadvantage & References \\
\hline Bioremediation & $\begin{array}{l}\text { Moderate cost, no waste } \\
\text { generation, minimum or no } \\
\text { disturbance to the soil, no } \\
\text { ecosystem disruption, minimal } \\
\text { energy requirement, large } \\
\text { contaminants handled at a time. }\end{array}$ & $\begin{array}{l}\text { Not recommended for non-biodegradable } \\
\text { compounds, products after biodegradation } \\
\text { can be more toxic, problematic upgrading } \\
\text { from laboratory scale, contaminant migration } \\
\text { through environmental resources, time } \\
\text { consuming process, remobilization of } \\
\text { stabilized contaminants due to changes in } \\
\text { hydrological and geochemical conditions, } \\
\text { inadequate benchmark values for field } \\
\text { application, requires deep understanding of } \\
\text { microbial process. }\end{array}$ & {$[37-41]$} \\
\hline ED/reverse ED & $\begin{array}{l}\text { Ion transport is rapid, effective } \\
\text { in wide pH ranges, no phase } \\
\text { change, not affected by } \\
\text { osmotic pressure. }\end{array}$ & $\begin{array}{l}\text { Stack clogging and membrane fouling, high } \\
\text { energy consumption, skilled labor, } \\
\text { compatibility of membrane and stacks } \\
\text { materials to feed stream solution is highly } \\
\text { required, current density limit, requires post } \\
\text { treatment and pretreatment. }\end{array}$ & [42-46] \\
\hline
\end{tabular}

The DMP set-up consists of three phases, namely, the donor phase, which contains the ion of interest for recovery, the sweep phase, which contains the donating ion to enable the counter transport and, most importantly, the IEM, which controls and allows selective transport of the ions. Cation exchange membranes (CEMs) are used for removing, recovering, separating and concentrating metal ions. Anion exchange membranes are applied during specific treatment of harmful anions such $\mathrm{Cl}^{-}, \mathrm{F}^{-}, \mathrm{HCO}_{3}{ }^{-}, \mathrm{NO}_{3}{ }^{-}, \mathrm{SO}_{4}{ }^{2-}$ and $\mathrm{AsO}_{4}{ }^{3-}$ [47].

The current work was inspired by the lack of a framework and methodological based analysis that extracts the various DMP phases for the selective recovery and removal of metal ions. In this context, the simplified review looks at the DMP set-up and its main features, DMP application areas, studied factors and research approach in the treatment of metal ions from the wastewater treatment settings. Again, the paper gives a succinct overview of process integration of DMP and other processes for the treatment of metal ions. The components considered in this review process give a perspective to future researchers on the methodological approach to DMP.

\section{Ion Exchange Membranes (IEM)}

Monopolar, amphoteric, bipolar and mosaic are the four (4) types of IEMs based on their charge functional groups and fixed ionic group pattern. Most IEMs for commercial applications are identified as monopolar with a single-line pattern [48-50]. Figure 1 is a schematic diagram for the classification of IEMs.

Depending on the charge group interconnection on the matrix phase of the membrane structure, IEMs are identified as homogenous and heterogeneous with varying properties and process advantages. In a homogeneous membrane, charged groups are bonded to a polymer backbone, while in a heterogeneous membrane, the ion exchange material is mixed with the polymeric matrix without chemical bonds between them [51-54].

Homogeneous IEMs have higher conductivity, perm selectivity and a more balanced distribution of functional sites, but they are more costly to produce and have more complex manufacturing phases. Comparatively, heterogeneous IEMs have better chemical stability and mechanical properties over the homogenous ones $[55,56]$. However, the low electrochemical properties of the heterogeneous IEMs are associated with ionic mobilization pathways, leakage of co-ions in the solution phase and the availability of inert fractions [52]. 
a)

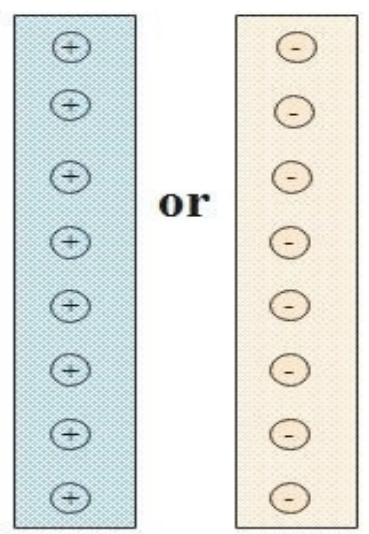

Monopolar b)

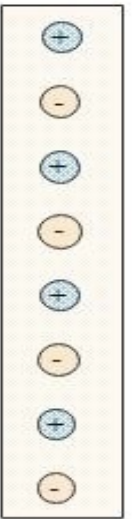

Amphoteric c)

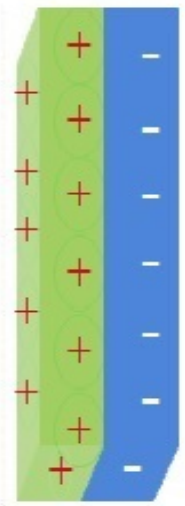

Bipolar d)

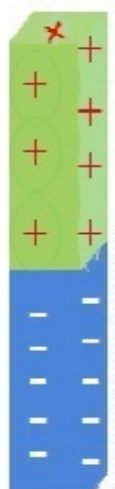

Mosaic

Figure 1. Categorized ion exchange membranes. (a) Positive or Negatively charged monopolar IEM, (b) Amphoteric IEM, (c) Bipolar IEM and (d) Mosaic IEM adapted from [49,50].

IEMs are designed and produced to have desirable characteristics such as high permselectivity, high conductivity, good mechanical strength, structural stability and high chemical and thermal stability [57-59]. The characteristics are also dependent on factors such as size of the ion exchange resin, resin loading, resin distribution, polymer used, solvent and method. Cation exchange membranes (CEMs) have proven higher stability in strong alkaline solutions than Anion exchange membranes (AEMs). Until recently, most commercially available CEMs and AEMs were homogeneous; Aciplex, Selemion Femion, Nafion, Fumasep, FKS, Ralex and Neosepta are known IEMs [51,60,61]. Figure 2 illustrates a typical transport pathway of ions through a homogenous CEM (Figure 2a) and heterogeneous AEM (Figure 2b).

a)

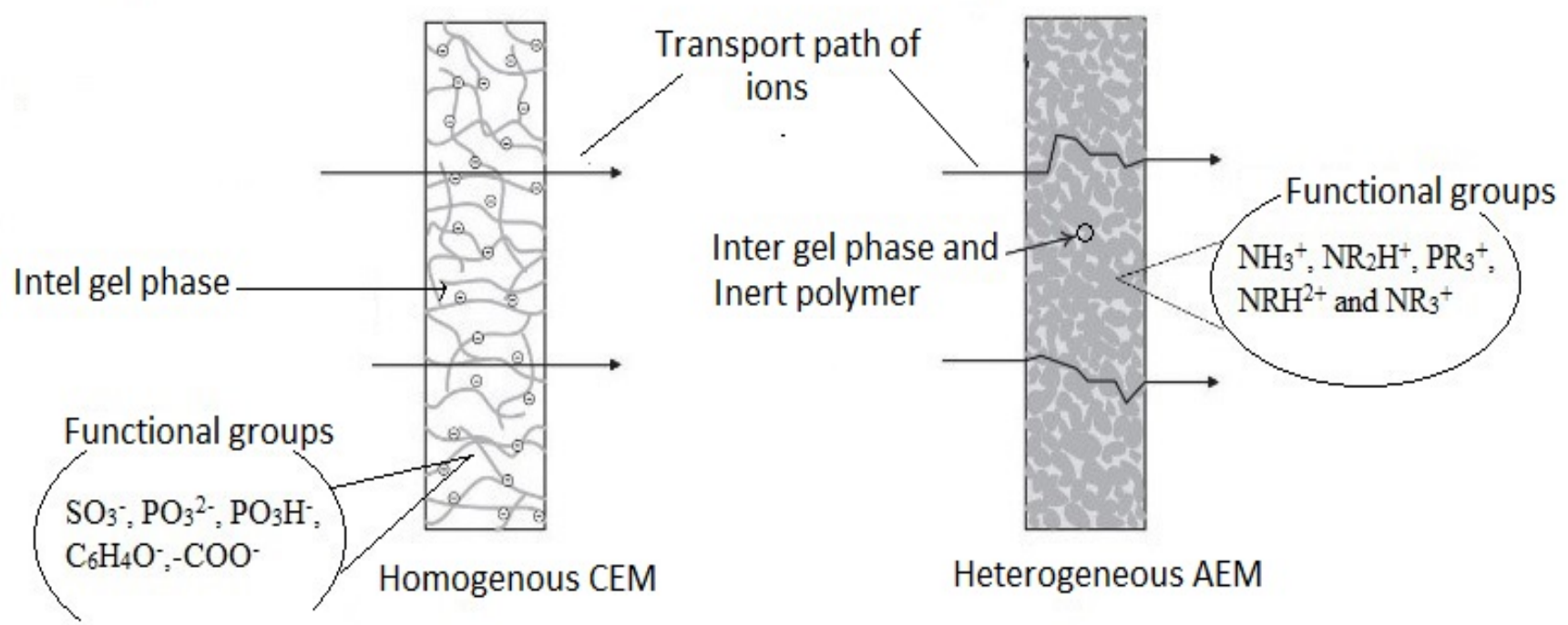

Figure 2. Ions pathway through a homogeneous CEM (a) and heterogeneous AEM (b).

Non-commercial membranes are often developed for performance evaluation and comparison with commercial membranes. These membranes are either synthesized or result from structural modification of existing membranes. To develop the surface, permselectivity efficiency and ion exchange capacity (IEC) of any membrane, various prepara- 
tion and modification techniques are applied, which include phase inversion, irradiation and film etching, microfabrication, film stretching, sintering of powders, track-etching, electro-deposition, sol-gel process and coating (dip coating, in situ polymerization, plasma polymerization, interfacial polymerization) $[62,63]$. However, surface engineering and modification is focused on the use of solvent-free technologies.

In short, IEM characteristics such as ion conductivity, hydrophilicity and hydrophobicity, ionic properties, embedded ion exchange groups, charge density and membraneion-affinity are the foundation for application in various ion exchange processes, which includes DMP $[50,64,65]$. The selectivity transport functionality of the membrane (characterized by morphology and microstructural variation) for target ions in the midst of multivalent ions influences their choice to achieve various DMP separation objectives. For target metal ions, the CEM (Figure 2a) is used.

The activation of CEMs prior to usage in a DMP system is essential to achieve a high membrane hydration. It ensures the setting up of transport pathways for the permeation of ions. Crucial to the conditioning process is the removal of impurities and factory defects from the surface of the membrane. Immersion and conditioning in acid is commonly adopted by researchers [66].

The sequence of conditions commence with immersion in $\mathrm{H}_{2} \mathrm{O}_{2}$, rinsing in distilled water or boiling water and is proceeded with acid conditioning with $\mathrm{HCl}, \mathrm{H}_{2} \mathrm{SO}_{4}$ and / or $\mathrm{HNO}_{3}$ at an elevated temperature of $\leq 90{ }^{\circ} \mathrm{C}$ [66-68]. The treatment chain is then completed by final rinsing in either deionized water at high or normal temperature. However, most treatments do not opt for $\mathrm{HNO}_{3}$ conditioning. Further treatment of the CEMs with $1 \%$ dilute $\mathrm{HCl}$ for $3 \mathrm{hrs}$ enhances ionic transport by increasing the inter-pore hydration of the membrane. Other procedures use $\mathrm{NaOH}$ neutralization in between two acid conditioning steps that alternate between $\mathrm{HCl}$ and $\mathrm{H}_{2} \mathrm{SO}_{4}$ at different treatment times and temperatures, including room temperature, for the same membrane $[69,70]$.

\section{Donnan Membrane Cell}

Four modules, notably the plate and frame, spiral wound, hollow fiber and the tubular type [71-73], are known in the membrane industry. However, two modules are applicable in the DMP system as there is the requirement of separate solutions flowing on either side of the membrane for counter exchange of the ions. These are the plate and frame and the tubular modules. The plate and frame modules are one of the earliest in the membrane industry and consist of a flat sheet membrane and a mesh spacer sandwiched between two blocks and plates. The tubular module consists of smaller tubular compartment housing membranes that are fitted into a larger tube [74]. Flat sheet modules have low performance characteristics, while tubular modules have medium performance characteristics, based on performance parameters such as promoting high cross flow rate, high filtering area to volume packing ratio and a pre-treatment requirement.

Various compartments to contain the donor and sweep phase solutions and membrane have been developed over the years. These modules are designed to meet main design criteria cited by [17] for DMP. These compartments are mostly made from materials such as borosilicate glass, Plexiglas $\left(\mathrm{C}_{5} \mathrm{O}_{2} \mathrm{H}_{8}\right)_{\mathrm{n}}, \mathrm{PVC}\left(\mathrm{C}_{2} \mathrm{H}_{3} \mathrm{Cl}\right)_{\mathrm{n}}$ and Teflon $\left(\mathrm{C}_{2} \mathrm{~F}_{4}\right)_{\mathrm{n}}$. A simple two-compartment cell has seen development with the attachment of external donor and sweep side vessels. Flow patterns are set-up with compressed air (Figure 3a), magnetic stirrer (Figure 3b) and shaking blocks or baffles (Figure 3c). In addition, turbulence at the membrane solution surface can be caused by increasing the flow rate of the electrolytic solution for a DMP compartment in Figure 3d. Zhao et al. [75] used a similar set-up as demonstrated in Figure $3 c$ and called it a point of use dialyzer. Additionally, cell arrangements vary and hybrid structures have included a 20 cell pair mounted with CEMs, 11 cells consisting of 5 feed and 6 sweep cells and a 3-4 membrane cell [76-78]. 
a)

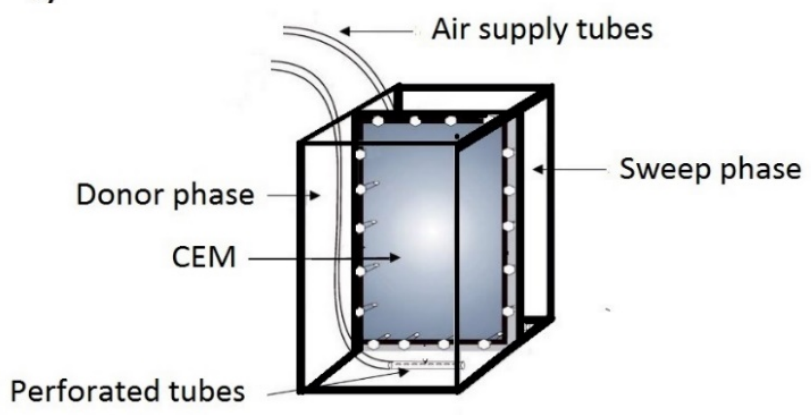

c)

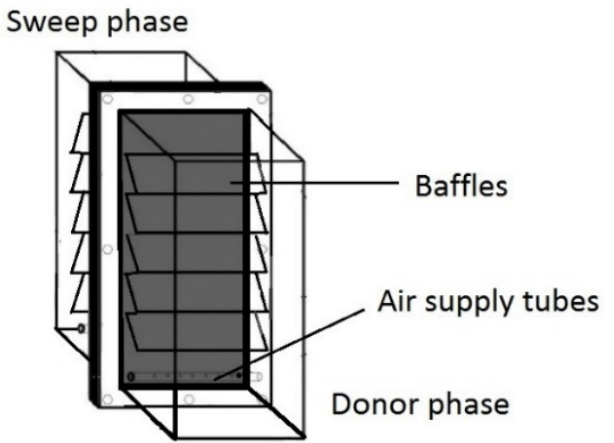

b)
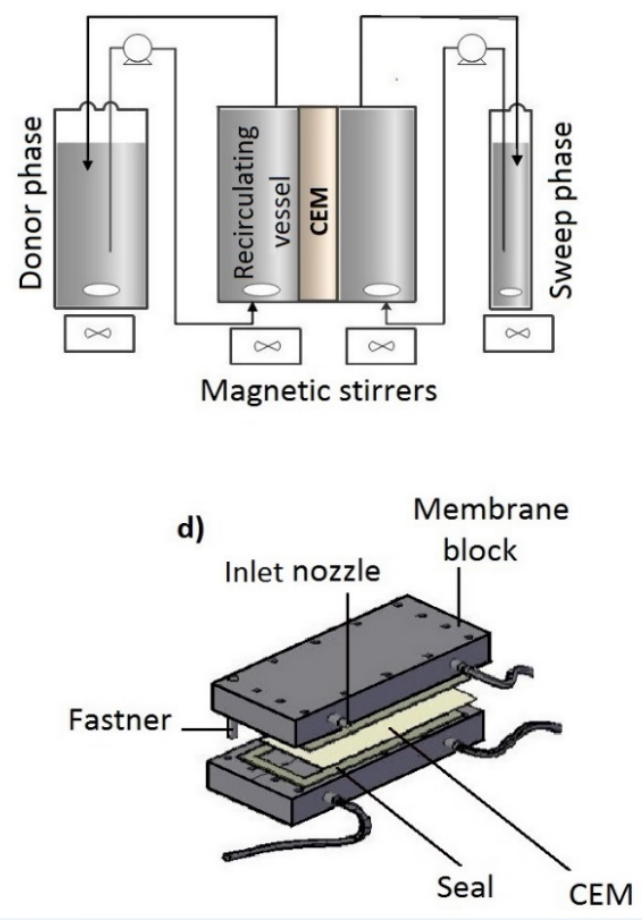

Figure 3. Donnan Membrane Process Cell Designs: (a) a simple compartment with compressed air agitation; (b) Compartment with external vessels and a mixing unit; (c) Point of Use systems; (d) Donnan membrane rig.

\section{Transport Mechanism}

In 1924, F.G Donnan discovered the Donnan equilibrium from the electrostatic repulsion of co-ions by the IEM. When using alum, the donor and sweep phases may contain the electrolytic solutions of aluminum sulfate from a potable water treatment residue (PWTR) and hydrochloric acid, respectively. At a level of polarization, dissociation of the acidic salt occurs at the membrane-solution interface and exchange commences. Figure 4 illustrates the ideal exchange mechanism of aluminum and hydrogen ions through a CEM. As the counter transport occurs, a concurrent electrostatic exclusion of sulfate and chloride co-ions by the Coulomb forces of the fixed ions in the membrane matrix also takes place [79]. From Figure 4, the counter transport of $\mathrm{Al}^{3+}-\mathrm{H}^{+}$is a three-stage process that involves the convective mass transfer of $\mathrm{Al}^{3+}$ from the donor solution (1) to the solution-membrane interface (w1) and the diffusion of the metal ion through the ion exchange membrane donor side to the membrane sweep side ( $\mathrm{m} 1$ to $\mathrm{m} 2$ ). This is followed by convective mass transfer of the ions from the membrane solution interface (w2) to the sweep solution (2).

Since the ion transport is time dependent, the exchange continues until chemical potential gradient equilibrium and counter ion transport equilibrium is reached when electroneutrality is established between the electrolytic solutions. Consequently, the aluminum in the donor solution decreases. The ion of interest is now recovered in a concentrated form in the sweep solution. The PWTR solution, which contains aluminum sulphate, would then be recovered as aluminum chloride. The aluminum chloride can be used as a coagulant. The significance of aluminum chloride recovery eventually leads to recycling, re-use and purification. 


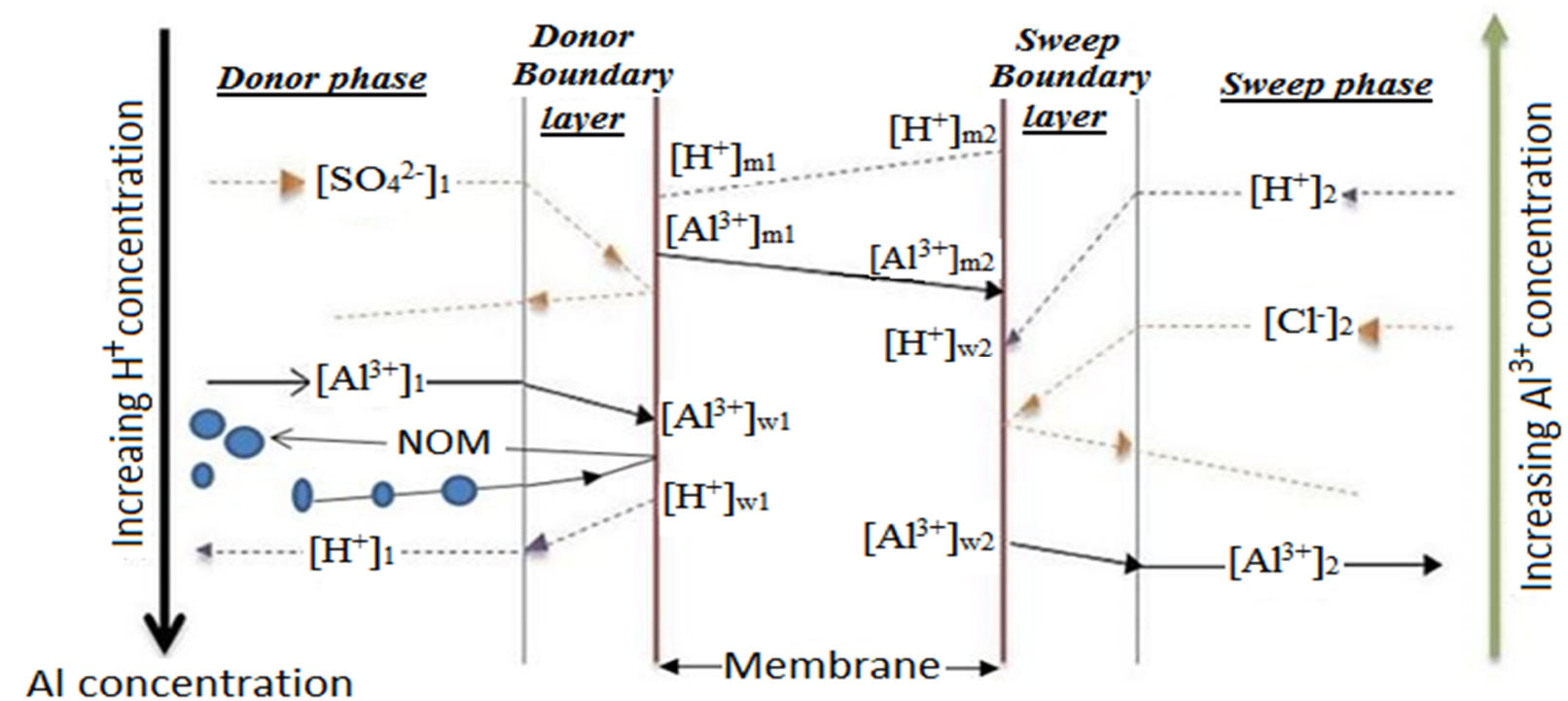

Figure 4. $\mathrm{Al}^{3+}-\mathrm{H}^{+}$transport through a cation exchange membrane.

The entropic gain by the exchanging of the monovalent metal ion and the trivalent metal ion can be expressed by the Donnan potentials of each metal specie. Generally, the Donnan potential for each metal specie (i) by their concentrations in each phase of the membrane $[80,81]$ is expressed as

$$
E_{D o n}=\frac{R T}{F} \operatorname{In}\left[\frac{a_{i, d}}{a_{i, s}}\right]^{\frac{1}{z}}
$$

where $E_{D o n}$ is the Donnan potential, $R$ is the gas constant $(8.314 \mathrm{~J} / \mathrm{kmol}), F$ is the Faraday constant $(96485 \mathrm{C} / \mathrm{mol}), T$ is the temperature $(\mathrm{K}), z$ is the valence of the metal ion and $a_{i, d}$ and $a_{i, s}$ are the activity of the metal ions in their respective phases.

When the counter exchange of the metal strives towards equilibrium, concentration of the metal ions is not equal; rather, the ratio of the valance of the metal ions to the power one equilibrates [82,83]. The equilibration theory of the metal species in both phases, in a typical case of the transport between trivalent aluminum and monovalent hydrogen, will be:

$$
\left[\frac{a_{A l^{3+}, d}}{a_{A l^{3+}, s}}\right]^{\frac{1}{3}}=\left[\frac{a_{H^{+}, d}}{a_{H^{+}, d}}\right]^{1}
$$

\section{Trends for Target Metal Ion}

The Donnan membrane process applications cover various industries spanning from the mineral process to the water and wastewater treatment industry. Depending on the DMP configuration, operating variables that affect recovery, separation and concentration of target metal ions are the concentration and flowrates of donor and sweep phases, electrolytic sweep solution, valence of counter ion, $\mathrm{pH}$, experimental duration, membrane type and morphology [84].

Most researchers use the one-factor at a time (OFAT) approach to evaluate the transport of metal ions. In OFAT, one factor is varied while the other variables are kept constant. Using OFAT, multiple experiments cannot be run, while a high number of experiments makes it cost intensive and time and resource consuming, with the inability to assess the interactive effect of variable optimal settings [85-87].

The statistical approach, also known as design of experiment (DOE), allows researchers to evaluate the independent and interacting effect of various process variables under consideration. Therefore, statistical models were developed that aid in process optimization [88-90]. 
Two relevant polynomial models are often involved. The first model, as seen in Equation (3), is for special cases, and this includes first-degree models $(d=1)$. The second degree model $(\mathrm{d}=2)$ is also expressed in Equation (4) [91] as:

$$
\begin{gathered}
Y=\beta_{o}+\sum_{i=1}^{k} \beta_{i} x_{i}+\epsilon \\
Y=\beta_{0}+\sum_{i=1}^{k} \beta_{i} x_{i}+\sum_{i<j} \sum \beta_{i j} x_{i} x_{j}+\sum_{i=1}^{k} \beta_{i i} x_{i}^{2}+\epsilon
\end{gathered}
$$

where $Y, \beta_{0}, \beta_{i}, x_{i}$ and $\epsilon$ are the characteristic response, constant term, coefficient, independent process variable and random experimental error at a zero mean, respectively.

A statistical approach has been used in only a few DMP studies involving target metal ions to assess the impact of process variables on recovery. A face centered central composite model developed for $\mathrm{Al}^{3+}$ considered the donor phase concentration, donor phase flowrate, sweep concentration and sweep flowrate [92]. Furthermore, screening studies for the four factors indicated that the sweep concentration had an insignificant effect on aluminum recovery [93]. As such, a Box-Behnkein model was developed using the donor concentration, donor flowrate and sweep concentration as factors for the design matrix.

Kinetic models have been developed for monovalent $\left(\mathrm{Na}^{+}, \mathrm{K}^{+}, \mathrm{Cs}^{+}\right.$and $\left.\mathrm{Ag}^{+}\right)$, divalent $\left(\mathrm{Ca}^{2+}, \mathrm{Ba}^{2+}, \mathrm{Mg}^{2+}\right.$ and $\left.\mathrm{Sr}^{2+}\right)$ and trivalent $\left(\mathrm{Al}^{3+}\right)$ metal ions based on Fick's and NernstPlanck's equations for ion fluxes [94-99]. Interestingly, all kinetic models for the mass transfer of the metal ions through the membrane have been conducted using the Nafion 117 membrane. Different commercially available Nafion membranes for possible DMP studies and their respective properties are presented in Table 2 [100-107].

\begin{tabular}{|c|c|c|c|c|}
\hline Nafion & Formation & Equivalent Weight $\left(\mathrm{g} \mathrm{eq}^{-1}\right.$ ) & Nominal Thickness $(\mu \mathrm{m})$ & Basic Weight $\left(\mathrm{g} \mathrm{m}^{-2}\right)$ \\
\hline N 115 & \multirow{3}{*}{ Extrusion } & 1100 & 127 & 250 \\
\hline N 117 & & 1100 & $178-183$ & 360 \\
\hline N 1035 & & 1000 & 89 & 175 \\
\hline NR 212 & \multirow{2}{*}{ Solution casted } & 1100 & $50-51$ & 100 \\
\hline NR 211 & & 1100 & 25.4 & 50 \\
\hline $\mathrm{XL}$ & \multirow{3}{*}{ Reinforced } & 1100 & 27.5 & 55 \\
\hline $\mathrm{HP}$ & & - & 20 & 43.5 \\
\hline 424 & & 1100 & 180 & 540 \\
\hline 1110 & Extrusion & 1100 & 254 & 500 \\
\hline
\end{tabular}

Table 2. Commercially available Nafion membranes with their respective properties.

\subsection{Single Stage}

Laboratory scale experiments for the recovery and removal of metal ions are reviewed in a single stage DMP process as shown in Table 3. Most of the donor phase solutions from industrial streams required pre-treatment such as acidification and filtration prior to DMP. 
Table 3. Target metal ion recovery using DMP only.

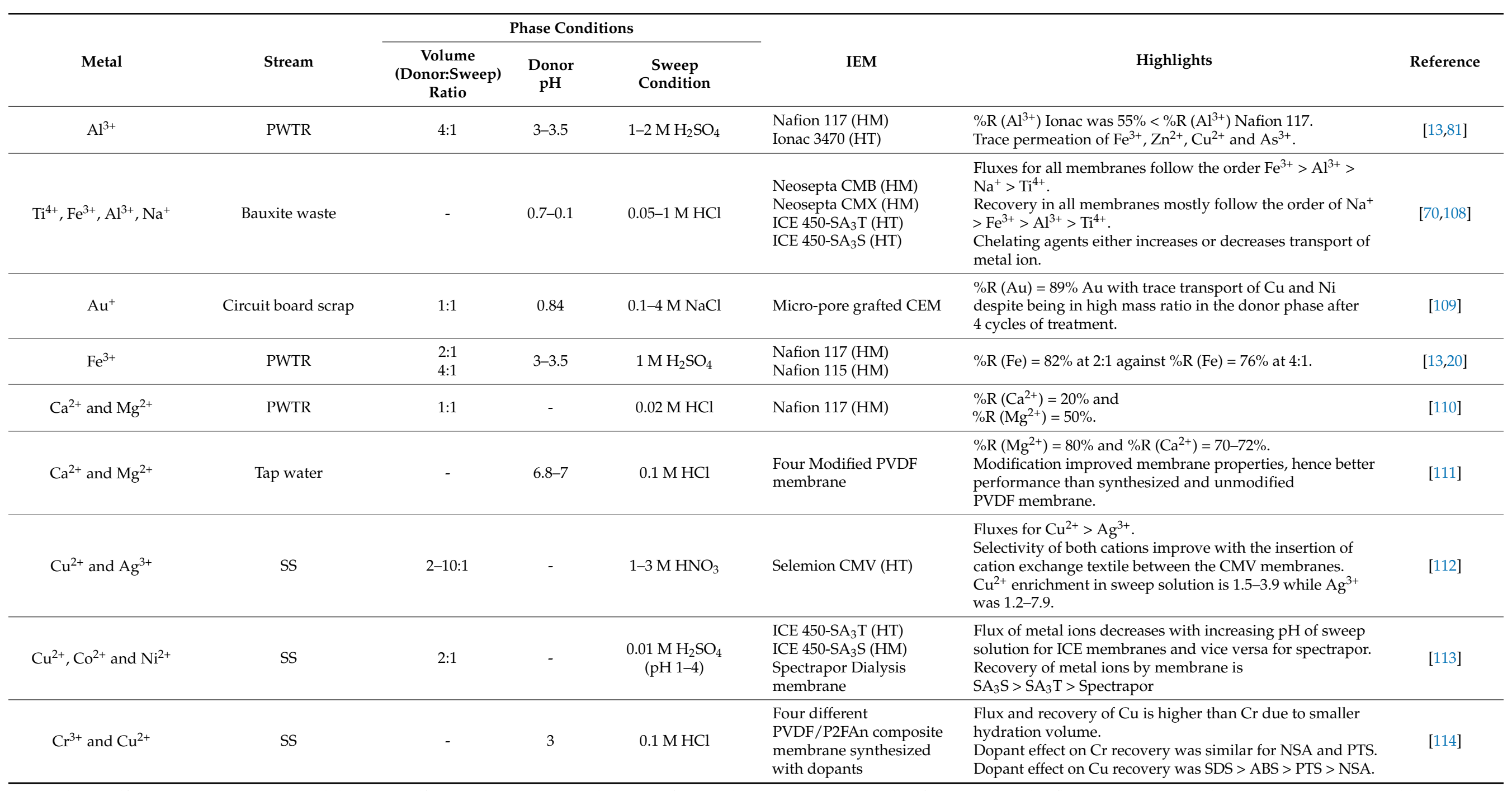

Toluenesulfonate, NSA-1,3 (6 or 7)-naphthalene trisulfonic acid; ABS-o-aminobenzen sulfonic acid; SDS—-sodium dodecyl sulfate; P2Fan—poly2-fluoroaniline; SS—-synthetic solution; PWTR—Potable water treatment residue. 


\subsection{Multi-Treatment Technologies}

To achieve synergic advantage in target metal ion separation, recovery and concentration, individual process limitations must be resolved.

The DMP process has been used as a possible pre-treatment for the removal of ion inhibitors, fouling and scaling sediments and as a post-treatment to further remove target ions. Table 4 consists of two stage combinative processes for the recovery. The Donnan membrane process has been integrated in three or more multi-stage processes such as the recycling of the lithium ion battery [115] and recovery of Fe from Fe-PWTR by integrating DMP with recovery and purification technologies such as acid leaching, adsorption with activated carbon, ultrafiltration and caustic treatment [20].

DMP in reverse osmosis (RO) and ion exchange (IEX) application studies looked into regeneration of resins using $\mathrm{RO}$ brines as the sweep phase with DMP as the regeneration step $[78,116]$. In using DMP as a pretreatment to $\mathrm{RO}$, the performance is affected by monovalent to multivalent ion ratio in the feed stream [78].

Additionally, DMP as a pretreatment in ED and reverse ED would change the ionic composition of the feed solution, thereby increasing the limiting current density of the solution before desalination takes place, and also reducing scaling [76,83]. While a CEM or AEM would be considered for the DMP in a DMP-RO system, Rózańska and Wiśniewski [117] used an integrated system made up of Selemion-CMV and Neosepta AFN, which are CEM's and AEM's, respectively.

Furthermore, the introduction of DMP in coagulation established that coagulant application at the sweep side provided extra driving ions for counter transport of target ions [118]. Table 4 shows the application of DMP for the treatment of target metals.

Table 4. Donnan membrane process and other treatment technologies.

\begin{tabular}{|c|c|c|c|c|}
\hline Combined Process & $\begin{array}{c}\text { Target } \\
\text { Metal/Ion }\end{array}$ & $\begin{array}{l}\text { Feed Phase } \\
\text { for DMP }\end{array}$ & Comments & Reference \\
\hline Electrodialysis & $\mathrm{Ca}^{2+}$ and $\mathrm{Mg}^{2+}$ & Brackish solution & $\begin{array}{l}\text { Desalination increased by } \\
21 \% \text { with observed } \\
\text { reduction in energy } \\
\text { consumption after } 79-89 \% \\
\mathrm{Ca}^{2+} \text { and } 75-90 \% \mathrm{Mg}^{2+} \text {. }\end{array}$ & {$[76,117,119,120]$} \\
\hline Reverse electrodialysis & $\mathrm{Ca}^{2+}$ and $\mathrm{Mg}^{2+}$ & River and sea water & $\begin{array}{l}\text { Gross and net power } \\
\text { density improved by } \\
1.4-9 \% \text { and } 6.3 \% \text {, } \\
\text { respectively. }\end{array}$ & [83] \\
\hline Reverse Osmosis & $\mathrm{Ca}^{2+}$ and $\mathrm{Mg}^{2+}$ & $\begin{array}{l}\text { Potato Processing waste } \\
\text { water and Tap water }\end{array}$ & $\begin{array}{l}\text { DMP increases RO } \\
\text { treatment by } 16 \% \text { and } 47 \% \\
\text { more for wastewater and } \\
\text { tap water. }\end{array}$ & [78] \\
\hline Struvite & $\begin{array}{l}\mathrm{Zn}^{2+}, \mathrm{K}^{+}, \mathrm{Na}^{+}, \mathrm{Mg}^{2+} \\
\text { and } \mathrm{Fe}^{3+}\end{array}$ & Hydrolyzed sludge liquid & $\begin{array}{l}\text { Struvite composition met } \\
\text { regulatory requirement as } \\
\text { DMP recovery of metal } \\
\text { composition was high. }\end{array}$ & [121] \\
\hline
\end{tabular}

\subsection{Future Prospects}

The Donnan membrane process, unlike the pressure-driven membrane process, is a potential gradient process that is caused by concentration and the driving force. However, over 95 years after the inception of DMP, the technology is yet to be fully researched and have its full potential understood. As an extremely slow kinetic process for ion transport that takes a longer period to achieve equilibrium, and concentration and separation of metal species, many approaches have not geared towards industrial applications $[122,123]$. Therefore, there is the proposed need for the integration of DMP to other separation processes 
rather than have a single DMP system, as cited in Table 2, where DMP is incorporated with other processes.

Another possible deterrent to DMP use is the membrane's higher purchase price and variable selectivity [124]. However, this is the situation for every emerging technology as initial purchase affects the total expenditure cost. Research and development are, therefore, geared towards addressing such problems. The cost will decline when global demand soars with progress in research and development towards cheaper membrane production costs.

There is little knowledge in the literature about factors like donor flowrate, electrolytic sweep solution flowrate, $\mathrm{pH}$ and experimental length, as well as their synergistic effect on separation, recovery and concentration of target metal ions. As a consequence, future research is needed. The various documented research studies do not make wide and industrial realistic variations to these process conditions. Additionally, understanding of the selectivity of IEM with multi-ion solutions should be given attention, as CEMs might be known to permeate target ion; however, the transport of non-targeted ions would occur in comparatively low to high concentrations.

\section{Conclusions}

The deployment of the Donnan membrane process for separation, recovery and concentration of metal ions is feasible with recommendable performance. This work attempted to give a succinct account of the DMP on target metal ions, which includes the cells, IEM, applications and treatment outcomes. This approach provides a quick referencing opportunity for expanding the prospects of DMP on target metal ions. For instance, the propensity of DMP to selectively recover aluminum whilst rejecting organics places it a step ahead over other techniques for recovering metals, specifically heavy metals. Consequently, stakeholders investing in Donnan membrane technology with real-time monitoring in metal ion treatment are poised to provide significant opportunities for socio-economic growth and development.

Author Contributions: Conceptualization, D.A.-S. and S.R.; Funding acquisition, L.V.P.; writing draft, D.A.-S., E.K.T. and E.O.E.; reviewing and editing, S.R. and L.V.P.; supervision: S.R. and E.K.T.; project administration: S.R. and E.K.T. All authors have read and agreed to the published version of the manuscript.

Funding: This research received a part funding under the Water Research Commission of South Africa project with identification WRC/240.

Institutional Review Board Statement: Not applicable.

Informed Consent Statement: Not applicable.

Data Availability Statement: Data sharing not applicable.

Acknowledgments: The authors are thankful to the Chemical Engineering Departments of Durban University of Technology, South Africa.

Conflicts of Interest: The authors declare no conflict of interest.

\section{References}

1. Aghalari, Z.; Dahms, H.; Sillanpää, M.; Sosa-Hernandez, J.E.; Parra-Saldívar, R. Effectiveness of wastewater treatment systems in removing microbial agents: A systematic review. Glob. Health 2020, 16, 13. [CrossRef]

2. Carvajal-Flórez, E.; Cardona-Gallo, S.-A. Technologies applicable to the removal of heavy metals from landfill leachate. Environ. Sci. Pollut. Res. 2019, 26, 15725-15753. [CrossRef] [PubMed]

3. Shen, X.; Chi, Y.; Xiong, K. The effect of heavy metal contamination on humans and animals in the vicinity of a zinc smelting facility. PLoS ONE 2019, 14, e0207423. [CrossRef]

4. Ananda Jayalal, T.B.; Jayaruwan Bandara, T.W.M.A.; Mahawithanage, S.T.C.; Wansapala, M.A.J.; Galappaththi, S.P.L. A quantitative analysis of chronic exposure of selected heavy metals in a model diet in a CKD hotspot in Sri Lanka. BMC Nephrol. 2019, 20, 1-14. [CrossRef] [PubMed] 
5. Mohammadi, A.A.; Zarei, A.; Esmaeilzadeh, M.; Taghavi, M.; Yousefi, M.; Yousefi, Z.; Sedighi, F.; Javan, S. Assessment of Heavy Metal Pollution and Human Health Risks Assessment in Soils Around an Industrial Zone in Neyshabur, Iran. Biol. Trace Elem. Res. 2020, 195, 343-352. [CrossRef] [PubMed]

6. $\quad$ Fakhri, Y.; Saha, N.; Miri, A.; Baghaei, M.; Roomiani, L.; Ghaderpoori, M.; Taghavi, M.; Keramati, H.; Bahmani, Z.; Moradi, B.; et al. Metal concentrations in fillet and gill of parrotfish (Scarus ghobban) from the Persian Gulf and implications for human health. Food Chem. Toxicol. 2018, 118, 348-354. [CrossRef] [PubMed]

7. Crini, G.; Lichtfouse, E.; Crini, G.; Advantages, E.L. Advantages and disadvantages of techniques used for wastewater treatment. Environ. Chem. Lett. 2019, 17, 145-155. [CrossRef]

8. Lim, T.M.; Ulaganathan, M.; Yan, Q. Advances in membrane and stack design of redox flow batteries (RFBs) for medium- and largescale energy storage. In Advances in Batteries for Medium and Large-Scale Energy Storage; Elsevier: Amsterdam, The Netherlands, 2015; pp. 477-507.

9. Chen, H.; Wang, L. Posttreatment Strategies for Biomass Conversion. In Technologies for Biochemical Conversion of Biomass; Elsevier: Amsterdam, The Netherlands, 2017; pp. 197-217.

10. Alabi, A.; Alhajaj, A.; Cseri, L.; Szekely, G.; Budd, P.; Zou, L. Review of nanomaterials-assisted ion exchange membranes for electromembrane desalination. NPJ Clean Water 2018, 1, 1-22. [CrossRef]

11. Goh, P.S.; Ismail, A.F. Flat-Sheet Membrane for Power Generation and Desalination Based on Salinity Gradient; Elsevier B.V.: Amsterdam, The Netherlands, 2018.

12. Son, M.; Cho, K.H.; Jeong, K.; Park, J. Membrane and Electrochemical Processes for Water Desalination: A Short Perspective and the Role of Nanotechnology. Membranes 2020, 10, 280. [CrossRef]

13. Prakash, P.; SenGupta, A.K. Selective Coagulant Recovery from Water Treatment Plant Residuals Using Donnan Membrane Process. Environ. Sci. Technol. 2003, 37, 4468-4474. [CrossRef]

14. Sata, T. Ion Exchange Membranes: Preparation, Characterization, Modification and Application, 1st ed.; Royal Society of Chemistry: Cambridge, UK, 2007.

15. Luo, J.; Wu, C.; Xu, T.; Wu, Y. Diffusion dialysis-concept, principle and applications. J. Memb. Sci. 2011, 366, 1-16. [CrossRef]

16. Tanaka, Y. Donnan Dialysis. In Ion Exchange Membranes; Elsevier: Amsterdam, The Netherlands, 2015 ; pp. 445-457. ISBN 9780444633194.

17. Davis, T.A. Donnan Dialysis. In Membrane Separations; Academic Press: Annandale, NJ, USA, 2000; Volume 2, pp. $1701-1707$.

18. Pyrzynska, K. Preconcentration and Recovery of Metal Ions by Donnan Dialysis. Microchim. Acta 2006, 153, 117-126. [CrossRef]

19. Breytus, A.; Hasson, D.; Semiat, R.; Shemer, H. Removal of nitrate from groundwater by Donnan dialysis. J. Water Process Eng. 2020, 34, 101157. [CrossRef]

20. Keeley, J.; Jarvis, P.; Smith, A.D.; Judd, S.J. Coagulant recovery and reuse for drinking water treatment. Water Res. 2016, 88, 502-509. [CrossRef] [PubMed]

21. Sarkar, S.; SenGupta, A.K.; Prakash, P. The Donnan Membrane Principle: Opportunities for Sustainable Engineered Processes and Materials. Environ. Sci. Technol. 2010, 44, 1161-1166. [CrossRef] [PubMed]

22. Naushad, M.; Mittal, A.; Rathore, M.; Gupta, V. Ion-exchange kinetic studies for Cd(II), Co(II), Cu(II), and Pb(II) metal ions over a composite cation exchanger. Desalin. Water Treat. 2015, 54, 2883-2890. [CrossRef]

23. Tetteh, E.K.; Rathilal, S.; Chetty, M.; Kwaku Armah, E.; Asante-Sackey, D. Treatment of Water and Wastewater for Reuse and Energy Generation-Emerging Technologies. In Water and Wastewater Treatment; IntechOpen: London, UK, 2019.

24. Ramaswami, S.; Behrendt, J.; Otterpohl, R. Comparison of NF-RO and RO-NF for the Treatment of Mature Landfill Leachates: A Guide for Landfill Operators. Membranes 2018, 8, 17. [CrossRef]

25. Pangarkar, B.L.; Sane, M.G.; Guddad, M. Reverse Osmosis and Membrane Distillation for Desalination of Groundwater: A Review. ISRN Mater. Sci. 2011, 2011, 1-9. [CrossRef]

26. Judd, S.J. Membrane technology costs and me. Water Res. 2017, 122, 1-9. [CrossRef] [PubMed]

27. Madhura, L.; Kanchi, S.; Sabela, M.I.; Singh, S.; Bisetty, K. Inamuddin Membrane technology for water purification. Environ. Chem. Lett. 2018, 16, 343-365. [CrossRef]

28. Roy, S.; Ragunath, S. Emerging Membrane Technologies for Water and Energy Sustainability: Future Prospects, Constrains and Challenges. Energies 2018, 11, 2997. [CrossRef]

29. Moosavi, S.; Lai, C.W.; Gan, S.; Zamiri, G.; Akbarzadeh Pivehzhani, O.; Johan, M.R. Application of efficient magnetic particles and activated carbon for dye removal from wastewater. ACS Omega 2020, 5, 20684-20697. [CrossRef]

30. Ouyang, D.; Zhuo, Y.; Hu, L.; Zeng, Q.; Hu, Y.; He, Z. Research on the adsorption behavior of heavy metal ions by porous material prepared with silicate tailings. Minerals 2019, 9, 291. [CrossRef]

31. Anantha, R.K.; Kota, S. An evaluation of the major factors influencing the removal of copper ions using the egg shell (Dromaius novaehollandiae): Chitosan (Agaricus bisporus) composite. 3 Biotech 2016, 6, 83. [CrossRef]

32. Patel, H. Fixed-bed column adsorption study: A comprehensive review. Appl. Water Sci. 2019, 9, 45. [CrossRef]

33. Zueva, S.B. Current legislation and methods of treatment of wastewater coming from waste electrical and electronic equipment processing. In Waste Electrical and Electronic Equipment Recycling; Elsevier: Amsterdam, The Netherlands, 2018 ; pp. $213-240$.

34. Pohl, A. Removal of Heavy Metal Ions from Water and Wastewaters by Sulfur-Containing Precipitation Agents. Water Air Soil Pollut. 2020, 231, 503. [CrossRef] 
35. Zhang, Y.; Duan, X. Chemical precipitation of heavy metals from wastewater by using the synthetical magnesium hydroxy carbonate. Water Sci. Technol. 2020, 81, 1130-1136. [CrossRef]

36. Agoro, M.A.; Adeniji, A.O.; Adefisoye, M.A.; Okoh, O.O. Heavy Metals in Wastewater and Sewage Sludge from Selected Municipal Treatment Plants in Eastern Cape Province, South Africa. Water 2020, 12, 2746. [CrossRef]

37. Xia, S.; Song, Z.; Jeyakumar, P.; Shaheen, S.M.; Rinklebe, J.; Ok, Y.S.; Bolan, N.; Wang, H. A critical review on bioremediation technologies for Cr(VI)-contaminated soils and wastewater. Crit. Rev. Environ. Sci. Technol. 2019, 49, 1027-1078. [CrossRef]

38. Mishra, S.; Bharagava, R.N. Toxic and genotoxic effects of hexavalent chromium in environment and its bioremediation strategies. J. Environ. Sci. Health Part C 2016, 34, 1-32. [CrossRef]

39. Sharma, I. Bioremediation Techniques for Polluted Environment: Concept, Advantages, Limitations, and Prospects. In Trace Metals in the Environment-New Approaches and Recent Advances; IntechOpen: London, UK, 2021.

40. Zouboulis, A.I.; Moussas, P.A.; Psaltou, S.G. Groundwater and Soil Pollution: Bioremediation. In Encyclopedia of Environmental Health; Elsevier: Amsterdam, The Netherlands, 2019; pp. 369-381. ISBN 9780444639523.

41. Singh, T.; Bhatiya, A.K.; Mishra, P.K.; Srivastava, N. An effective approach for the degradation of phenolic waste. In Abatement of Environmental Pollutants; Elsevier: Amsterdam, The Netherlands, 2020; pp. 203-243.

42. Xue, S.; Wu, C.; Wu, Y.; Zhang, C. An optimized process for treating sodium acetate waste residue: Coupling of diffusion dialysis or electrodialysis with bipolar membrane electrodialysis. Chem. Eng. Res. Des. 2018, 129, 237-247. [CrossRef]

43. Brandt, M.J.; Johnson, K.M.; Elphinston, A.J.; Ratnayaka, D.D. Specialized and Advanced Water Treatment Processes. In Twort's Water Supply; Elsevier: Amsterdam, The Netherlands, 2017; pp. 407-473.

44. Merkel, A.; Ashrafi, A.M. An investigation on the application of pulsed electrodialysis reversal in whey desalination. Int. J. Mol. Sci. 2019, 20, 1918. [CrossRef] [PubMed]

45. Lee, J. Using Reverse Osmosis, Electrodialysis, and Nanofiltration to Increase Affordable Desalinated Groundwater Use in Texas. Maneto Undergrad. Res. J. 2019, 2, 1-28. [CrossRef]

46. Kingsbury, R.S.; Liu, F.; Zhu, S.; Boggs, C.; Armstrong, M.D.; Call, D.F.; Coronell, O. Impact of natural organic matter and inorganic solutes on energy recovery from five real salinity gradients using reverse electrodialysis. J. Memb. Sci. 2017, 541, 621-632. [CrossRef]

47. Wang, X.; Zhang, X.; Wu, C.; Han, X.; Xu, C. Anion exchange membranes with excellent monovalent anion perm-selectivity for electrodialysis applications. Chem. Eng. Res. Des. 2020, 158, 24-32. [CrossRef]

48. $\mathrm{Xu}, \mathrm{T}$. Ion exchange membranes: State of their development and perspective. J. Membr. Sci. 2005, 263, 1-29. [CrossRef]

49. Stenina, I.; Golubenko, D.; Nikonenko, V. Selectivity of Transport Processes in Ion-Exchange Membranes: Relationship with the Structure and Methods for Its Improvement. Int. J. Mol. Sci. 2020, 21, 5517. [CrossRef]

50. Luo, T.; Abdu, S.; Wessling, M. Selectivity of ion exchange membranes: A review. J. Membr. Sci. 2018, 555, 429-454. [CrossRef]

51. Wenten, I.G. Recent developments in heterogeneous ion-exchange membrane: Preparation, modification, characterization and performance evaluation. J. Eng. Sci. Technol. 2016, 11, 916-934.

52. Ariono, D. Khoiruddin Improving Ion-Exchange Membrane Properties by the Role of Nanoparticles. In Proceedings of the International Conference on Engineering, Science and Nanotechnology 2016 (ICESNANO 2016); AIP Publishing LLC: Melville, NY, USA, 2017; Volume 0300031.

53. Veerman, J.; Vermaas, D.A. Reverse electrodialysis. In Sustainable Energy from Salinity Gradients; Elsevier: Amsterdam, The Netherlands, 2016; pp. 77-133.

54. Strathmann, H.; Giorno, L.; Piacentini, E.; Drioli, E. Basic Aspects in Polymeric Membrane Preparation. In Comprehensive Membrane Science and Engineering; Elsevier: Amsterdam, The Netherlands, 2017; pp. 65-84.

55. Lee, S.; Meng, W.; Wang, Y.; Wang, D.; Zhang, M. Comparison of the property of homogeneous and heterogeneous ion exchange membranes during electrodialysis process. Ain Shams Eng. J. 2021, 12, 159-166. [CrossRef]

56. Ahmad, M.; Qaiser, A.A.; Huda, N.U.; Saeed, A. Heterogeneous ion exchange membranes based on thermoplastic polyurethane (TPU): Effect of PSS/DVB resin on morphology and electrodialysis. RSC Adv. 2020, 10, 3029-3039. [CrossRef]

57. Bulejko, P.; Stránská, E.; Weinertová, K. Properties and structure of heterogeneous ion-exchange membranes after exposure to chemical agents. J. Solid State Electrochem. 2017, 21, 111-124. [CrossRef]

58. Hong, J.G.; Gao, H.; Gan, L.; Tong, X.; Xiao, C.; Liu, S.; Zhang, B.; Chen, Y. Nanocomposite and nanostructured ion-exchange membrane in salinity gradient power generation using reverse electrodialysis. In Advanced Nanomaterials for Membrane Synthesis and its Applications; Elsevier: Amsterdam, The Netherlands, 2019; pp. 295-316.

59. Hassanvand, A.; Wei, K.; Talebi, S.; Chen, G.; Kentish, S. The Role of Ion Exchange Membranes in Membrane Capacitive Deionisation. Membranes 2017, 7, 54. [CrossRef] [PubMed]

60. Liu, Z.; Sajjad, S.D.; Gao, Y.; Yang, H.; Kaczur, J.J.; Masel, R.I. The effect of membrane on an alkaline water electrolyzer. Int. J. Hydrog. Energy 2017, 42, 29661-29665. [CrossRef]

61. Martí-Calatayud, M.C.; Buzzi, D.C.; García-Gabaldón, M.; Bernardes, A.M.; Tenório, J.A.S.; Pérez-Herranz, V. Ion transport through homogeneous and heterogeneous ion-exchange membranes in single salt and multicomponent electrolyte solutions. $J$. Membr. Sci. 2014, 466, 45-57. [CrossRef]

62. Jiang, S.; Li, Y.; Ladewig, B.P. A review of reverse osmosis membrane fouling and control strategies. Sci. Total Environ. 2017, 595, 567-583. [CrossRef] 
63. Díez, B.; Rosal, R. A critical review of membrane modification techniques for fouling and biofouling control in pressure-driven membrane processes. Nanotechnol. Environ. Eng. 2020, 5, 1-21. [CrossRef]

64. Chandra, A.; Bhuvanesh, E.; Chattopadhyay, S. Physicochemical interactions of organic acids influencing microstructure and permselectivity of anion exchange membrane. Colloids Surf. A Physicochem. Eng. Asp. 2019, 560, 260-269. [CrossRef]

65. Ran, J.; Wu, L.; He, Y.; Yang, Z.; Wang, Y.; Jiang, C.; Ge, L.; Bakangura, E.; Xu, T. Ion exchange membranes: New developments and applications. J. Memb. Sci. 2017, 522, 267-291. [CrossRef]

66. Napoli, L.; Lavorante, M.J.; Franco, J.; Sanguinetti, A.; Fasoli, H. Effects on nafion ${ }^{\circledR} 117$ membrane using different strong acids in various concentrations. J. New Mater. Electrochem. Syst. 2013, 16, 151-156. [CrossRef]

67. Duan, Q.; Wang, H.; Benziger, J. Transport of liquid water through Nafion membranes. J. Memb. Sci. 2012, 392-393, 88-94. [CrossRef]

68. Iben Nasser, I.; Ahmed, C. Application of donnan dialysis for cyanide removal from aqueous solutions. Int. J. Environ. Res. 2015, 9, 505-510.

69. Ersoz, M.; Kara, H. Cobalt(II) and Nickel(II) Transfer through Charged Polysulfonated Cation Exchange Membranes. J. Colloid Interface Sci. 2000, 232, 344-349. [CrossRef] [PubMed]

70. Çengeloğlu, Y.; Kir, E.; Ersöz, M. Recovery and concentration of Al(III), Fe(III), Ti(IV), and Na(I) from red mud. J. Colloid Interface Sci. 2001, 244, 342-346. [CrossRef]

71. Ezugbe, E.O.; Rathilal, S. Membrane Technologies in Wastewater Treatment: A Review. Membranes 2020, 10, 89. [CrossRef] [PubMed]

72. Gruskevica, K.; Mezule, L. Cleaning Methods for Ceramic Ultrafiltration Membranes Affected by Organic Fouling. Membranes 2021, 11, 131. [CrossRef]

73. Lee, S. Performance Comparison of Spiral-Wound and Plate-and-Frame Forward Osmosis Membrane Module. Membranes 2020, 10, 318. [CrossRef]

74. Baker, R.W. Membrane Technology and Application, 3rd ed.; John Wiley \& Sons Ltd.: West Sussex, UK, $2012 ;$ ISBN 9780470743720.

75. Zhao, B.; Zhao, H.; Dockko, S.; Ni, J. Arsenate removal from simulated groundwater with a Donnan dialyzer. J. Hazard. Mater. 2012, 215-216, 159-165. [CrossRef]

76. Wiśniewski, J.; Rózańska, A. Donnan dialysis for hardness removal from water before electrodialytic desalination. Desalination 2007, 212, 251-260. [CrossRef]

77. Garmes, H.; Persinb, F.; Sandeauxb, J.; Pourcellyb, G. Defluoridation of groundwater by a hybrid process combining adsorption and Donnan dialysis. Desalination 2002, 145, 287-291. [CrossRef]

78. Vanoppen, M.; Stoffels, G.; Demuytere, C.; Bleyaert, W.; Verliefde, A.R.D. Increasing RO efficiency by chemical-free ion-exchange and Donnan dialysis: Principles and practical implications. Water Res. 2015, 80, 59-70. [CrossRef]

79. Besha, A.T.; Tsehaye, M.T.; Aili, D.; Zhang, W.; Tufa, R.A. Design of Monovalent Ion Selective Membranes for Reducing the Impacts of Multivalent Ions in Reverse Electrodialysis. Membranes 2019, 10, 7. [CrossRef] [PubMed]

80. Miyoshi, H. Diffusion coefficients of ions through ion-exchange membranes for Donnan dialysis using ions of the same valence. Chem. Eng. Sci. 1997, 52, 1087-1096. [CrossRef]

81. Prakash, P.; Hoskins, D.; SenGupta, A.K. Application of homogeneous and heterogeneous cation-exchange membranes in coagulant recovery from water treatment plant residuals using Donnan membrane process. J. Membr. Sci. 2004, 237, 131-144. [CrossRef]

82. Gurreri, L.; Tamburini, A.; Cipollina, A.; Micale, G. Electrodialysis applications in wastewater treatment for environmental protection and resources recovery: A systematic review on progress and perspectives. Membranes 2020, 10, 146. [CrossRef]

83. Rijnaarts, T.; Shenkute, N.T.; Wood, J.A.; De Vos, W.M.; Nijmeijer, K. Divalent Cation Removal by Donnan Dialysis for Improved Reverse Electrodialysis. ACS Sustain. Chem. Eng. 2018, 6, 7035-7041. [CrossRef]

84. Asante-Sackey, D.; Rathilal, S.; Pillay, L.; Tetteh, E.K. Effect of ion exchange dialysis process variables on aluminium permeation using response surface methodology. Environ. Eng. Res. 2019, 25, 714-721. [CrossRef]

85. Abdulrasheed, M.; Zulkharnain, A.; Zakaria, N.N.; Roslee, A.F.A.; Abdul Khalil, K.; Napis, S.; Convey, P.; Gomez-Fuentes, C.; Ahmad, S.A. Response Surface Methodology Optimization and Kinetics of Diesel Degradation by a Cold-Adapted Antarctic Bacterium, Arthrobacter sp. Strain AQ5-05. Sustainability 2020, 12, 6966. [CrossRef]

86. Uhoraningoga, A.; Kinsella, G.K.; Henehan, G.T.; Ryan, B.J. The goldilocks approach: A review of employing design of experiments in prokaryotic recombinant protein production. Bioengineering 2018, 5, 89. [CrossRef]

87. Abou-Taleb, K.A.; Galal, G.F. A comparative study between one-factor-at-a-time and minimum runs resolution-IV methods for enhancing the production of polysaccharide by Stenotrophomonas daejeonensis and Pseudomonas geniculate. Ann. Agric. Sci. 2018, 63, 173-180. [CrossRef]

88. Tîțu, A.M.; Sandu, A.V.; Pop, A.B.; Tîțu, S.; Frățilă, D.N.; Ceocea, C.; Boroiu, A. Design of experiment in the milling process of aluminum alloys in the aerospace industry. Appl. Sci. 2020, 10, 6951. [CrossRef]

89. Seok, W.; Kim, G.H.; Seo, J.; Rhee, S.H. Application of the Design of Experiments and Computational Fluid Dynamics to Bow Design Improvement. J. Mar. Sci. Eng. 2019, 7, 226. [CrossRef]

90. Kumari, M.; Gupta, S.K. Response surface methodological (RSM) approach for optimizing the removal of trihalomethanes (THMs) and its precursor's by surfactant modified magnetic nanoadsorbents (sMNP)—An endeavor to diminish probable cancer risk. Sci. Rep. 2019, 9, 18339. [CrossRef] [PubMed] 
91. Kleijnen, J.P.C. Response surface methodology. Int. Ser. Oper. Res. Manag. Sci. 2015, 216, 81-104.

92. Asante-Sackey, D.; Rathilal, S.; Pillay, L.V.; Kweinor Tetteh, E. Ion Exchange Dialysis for Aluminium Transport through a Face-Centred Central Composite Design Approach. Processes 2020, 8, 160. [CrossRef]

93. Pillay, V.L.; Mophethe, M.; Asante-Sackey, D. The Development and Evaluation of a Donnan Dialysis Process for the Recovery and Reuse of Aluminium from Potable Water Treatment Residual Streams Report to the Water Research Commission; Water Research Commission: Pretoria, South Africa, 2018; ISBN 978-1-4312-0999-6.

94. Szczepański, P.; Szczepańska, G. Donnan dialysis-A new predictive model for non-steady state transport. J. Membr. Sci. 2017, 525, 277-289. [CrossRef]

95. Goswami, A.; Acharya, A.; Pandey, A.K. Study of Self-Diffusion of Monovalent and Divalent Cations in Nafion-117 Ion-Exchange Membrane. J. Phys. Chem. B 2001, 105, 9196-9201. [CrossRef]

96. Agarwal, C.; Chaudhury, S.; Pandey, A.K.; Goswami, A. Kinetic aspects of Donnan dialysis through Nafion-117 membrane. J. Membr. Sci. 2012, 415-416, 681-685. [CrossRef]

97. Agarwal, C.; Goswami, A. Nernst Planck approach based on non-steady state flux for transport in a Donnan dialysis process. J. Membr. Sci. 2016, 507, 119-125. [CrossRef]

98. Okada, T.; Xie, G.; Gorseth, O.; Kjelstrup, S.; Nakamura, N.; Arimura, T. Ion and water transport characteristics of Nafion membranes as electrolytes. Electrochim. Acta 1998, 43, 3741-3747. [CrossRef]

99. Prakash, P.; SenGupta, A.K. Modeling $\mathrm{Al}^{3+} / \mathrm{H}^{+}$ion transport in Donnan membrane process for coagulant recovery. AIChE J. 2005, 51, 333-344. [CrossRef]

100. Torres Duarte, L.M.; Domínguez Almaraz, G.M.; Torres Pacheco, C.J. Fatigue tests on the proton exchange membrane Nafion 115 (perfluorosulfonic acid) of fuel cells, under the biaxial modality: Tension and torsion. Mater. Sci. Energy Technol. 2019, 2, 22-28. [CrossRef]

101. Nazir, N.A.; Kyu, T.; Reinsel, A.M.; Espe, M.; Nosaka, M.; Kudo, H.; Nishikubo, T. Incorporation of hyperbranched supramolecules into nafion ionic domains via impregnation and in-situ photopolymerization. Polymers 2011, 3, 2018-2038. [CrossRef]

102. Gagliardi, G.G.; Ibrahim, A.; Borello, D.; El-Kharouf, A. Composite polymers development and application for polymer electrolyte membrane technologies-A review. Molecules 2020, 25, 1712. [CrossRef]

103. Leddy, J. Modification of nafion on membranes: Tailoring properties for function. ACS Symp. Ser. 2015, 1213, 99-133.

104. Tang, H.; Pan, M. Nafion. Encyclopedia of Polymer Science and Technology; John Wiley \& Sons, Inc.: Hoboken, NJ, USA, 2015; pp. 1-39.

105. Klingele, M.; Breitwieser, M.; Zengerle, R.; Thiele, S. Direct deposition of proton exchange membranes enabling high performance hydrogen fuel cells. J. Mater. Chem. A 2015, 3, 11239-11245. [CrossRef]

106. Walkowiak-Kulikowska, J.; Wolska, J.; Koroniak, H. Polymers application in proton exchange membranes for fuel cells (PEMFCs). Phys. Sci. Rev. 2017, 2, 1-34.

107. Ling, X.; Bonn, M.; Domke, K.F.; Parekh, S.H. Correlated interfacial water transport and proton conductivity in perfluorosulfonic acid membranes. Proc. Natl. Acad. Sci. USA 2019, 116, 8715-8720. [CrossRef] [PubMed]

108. Çengeloğlu, Y.; Kir, E.; Ersoz, M.; Buyukerkek, T.; Gezgin, S. Recovery and concentration of metals from red mud by Donnan dialysis. Colloids Surf. A Physicochem. Eng. Asp. 2003, 223, 95-101. [CrossRef]

109. Agarwal, C.; Cattrall, R.W.; Kolev, S.D. Donnan dialysis based separation of gold(III) from electronic waste solutions using an anion exchange pore-filled membrane. J. Membr. Sci. 2016, 514, 210-216. [CrossRef]

110. Wang, Q.; Lenhart, J.J.; Walker, H.W. Recovery of metal cations from lime softening sludge using Donnan dialysis. J. Membr. Sci. 2010, 360, 469-475. [CrossRef]

111. Şahin, M.; Görçay, H.; Kir, E.; Şahin, Y. Removal of calcium and magnesium using polyaniline and derivatives modified PVDF cation-exchange membranes by Donnan dialysis. React. Funct. Polym. 2009, 69, 673-680. [CrossRef]

112. Berdous, D.; Akretche, D.E. Recovery of metals by Donnan dialysis with ion exchange textiles. Desalination 2002, 144, 213-218. [CrossRef]

113. Ersöz, M.; Çengelolu, Y.; Kir, E.; Koyuncu, M.; Yazicigil, Z. Transport of Cu(II) ions through charged cation-exchange membranes. J. Appl. Polym. Sci. 2001, 81, 421-427. [CrossRef]

114. Koseoglu, T.S.; Kir, E.; Ozkorucuklu, S.P.; Karamizrak, E. Preparation and characterization of P2FAn/PVDF composite cationexchange membranes for the removal of $\mathrm{Cr}(\mathrm{III})$ and $\mathrm{Cu}$ (II) by Donnan dialysis. React. Funct. Polym. 2010, 70, 900-907. [CrossRef]

115. Sonoc, A.C.; Jeswiet, J.; Murayama, N.; Shibata, J. A study of the application of Donnan dialysis to the recycling of lithium ion batteries. Hydrometallurgy 2018, 175, 133-143. [CrossRef]

116. Bryjak, M.; Poźniak, G.; Kabay, N. Donnan dialysis of borate anions through anion exchange membranes: A new method for regeneration of boron selective resins. React. Funct. Polym. 2007, 67, 1635-1642. [CrossRef]

117. Rózańska, A.; Wiśniewski, J. Modification of brackish water composition by means of Donnan dialysis as pretreatment before desalination. Desalination 2009, 240, 326-332. [CrossRef]

118. Oehmen, A.; Valerio, R.; Llanos, J.; Fradinho, J.; Serra, S.; Reis, M.A.M.M.; Crespo, J.G.; Velizarov, S. Arsenic removal from drinking water through a hybrid ion exchange membrane-Coagulation process. Sep. Purif. Technol. 2011, 83, 137-143. [CrossRef]

119. Rozanska, A.; Wisniewski, J.; Winnicki, T. Donnan dialysis with anion-exchange membranes in a water desalination system. Desalination 2006, 198, 236-246. [CrossRef]

120. Wiśniewski, J.; Różańska, A. Donnan dialysis with anion-exchange membranes as a pretreatment step before electrodialytic desalination. Desalination 2006, 191, 210-218. [CrossRef] 
121. Uysal, A.; Tuncer, D.; Kir, E.; Koseoglu, T.S. Recovery of nutrients from digested sludge as struvite with a combination process of acid hydrolysis and Donnan dialysis. Water Sci. Technol. 2017, 76, 2733-2741. [CrossRef] [PubMed]

122. Ben Hamouda, S.; Touati, K.; Ben Amor, M. Donnan dialysis as membrane process for nitrate removal from drinking water: Membrane structure effect. Arab. J. Chem. 2017, 10, S287-S292. [CrossRef]

123. Turki, T.; Amor, M. Ben Nitrate removal from natural water by coupling adsorption and Donnan dialysis. Water Sci. Technol. Water Supply 2017, 17, 771-779. [CrossRef]

124. Keeley, J.; Jarvis, P.; Judd, S.J. An economic assessment of coagulant recovery from water treatment residuals. Desalination 2012, 287, 132-137. [CrossRef] 